\title{
Assessing the potential of Sentinel-2 data for tracking invasive water hyacinth in a river branch
}

\author{
Romeu Gerardo $\odot^{\mathrm{a}, \mathrm{b}}$ and Isabel P. de Lima $\odot^{\mathrm{a}, \mathrm{b}, *}$ \\ ${ }^{a}$ University of Coimbra, Department of Civil Engineering, Faculty of Sciences and Technology, \\ Coimbra, Portugal \\ ${ }^{\mathrm{b}}$ University of Coimbra, Marine and Environmental Sciences Centre, Coimbra, Portugal
}

\begin{abstract}
Water hyacinth (Eichhornia crassipes) has become a threat to many aquatic environments worldwide. This aquatic weed presents a rapid reproductive capacity and outcompetes other aquatic plant species, forming dense, free-floating mats, which in many instances completely cover fresh-water surfaces. The infestation leads to several serious environmental (including ecological and socioeconomic) impacts that are hazardous to aquatic systems, disables human uses of surface waters, and affects hydraulic infrastructures (e.g., waterways and pumping stations). Our study explores the use of remote sensing tools to monitor and categorize the spread of water hyacinth, aiming at new insights into the detection, observation, and mapping of this invasive plant using vegetation indices and water indices calculated from multispectral data from satellite Sentinel-2, such as normalized difference vegetation index and normalized difference water index. The approach uses spatiotemporal information and has the potential to contribute to inform planners and decision-makers that are concerned with managing the plant by applying integrated measures. The case study deals with a small water course located in the downstream part of the Mondego river valley in Portugal, a country where water hyacinth is widely spread and constitutes a major problem, mainly in the irrigated agricultural areas of the Tagus, Sado, Mondego, and Lis rivers' basins. ( $)$ The Authors. Published by SPIE under a Creative Commons Attribution 4.0 International License. Distribution or reproduction of this work in whole or in part requires full attribution of the original publication, including its DOI. [DOI: 10.1117/1.JRS.16 .014511]
\end{abstract}

Keywords: remote sensing; multispectral satellite sensors; vegetation indices; water indices; normalized difference vegetation index; normalized difference water index.

Paper 210649 received Oct. 8, 2021; accepted for publication Jan. 24, 2022; published online Feb. 10, 2022.

\section{Introduction}

Water hyacinth, botanically known as Eichhornia crassipes (Mart.) Solms-Laubach, is a perennial aquatic weed that has become a threat to many aquatic environments worldwide. This aquatic freshwater plant, which is native to the Amazon basin in South America, has spread to other parts of the world since the 19th century, ${ }^{1-4}$ remaining the most troublesome aquatic weed both locally (across the areas affected) and globally. ${ }^{5-9}$ The International Union for Conservation of Nature rates water hyacinth as one of the hundred most harmful invasive species. $^{10}$

Eichhornia crassipes is now found in all continents except Antarctica and has invaded all tropical and subtropical countries as well as some parts of the Mediterranean basin. ${ }^{11-13}$ The plant grows fast at air temperatures from $20^{\circ} \mathrm{C}$ to $30^{\circ} \mathrm{C}$, but growth stops at low temperatures, approximately below $15^{\circ} \mathrm{C} .{ }^{14}$ Water hyacinth can tolerate $\mathrm{pH}$ up to 6 to 8 and eutrophic, still, or slow-moving freshwater systems. ${ }^{15}$ The species can grow and reproduce throughout the year, although flowering occurs mostly during spring and summer. ${ }^{16}$ Water hyacinth is a member of the monocotyledons family Pontederiacea ${ }^{17}$ and reproduces asexually using stolons and sexually by seeds. ${ }^{1,18}$ It is one of the most productive photosynthetic plants in the world. It presents a rapid multiplicative capacity that enables it to double its biomass in 6 to 14 days under favorable growth (climatic and water) conditions. ${ }^{19}$

*Address all correspondence to Isabel P. de Lima, iplima@uc.pt 
(a)

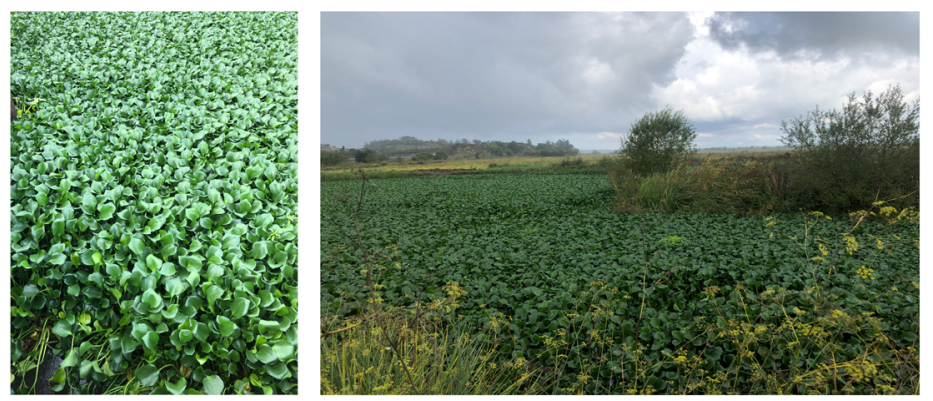

(b)
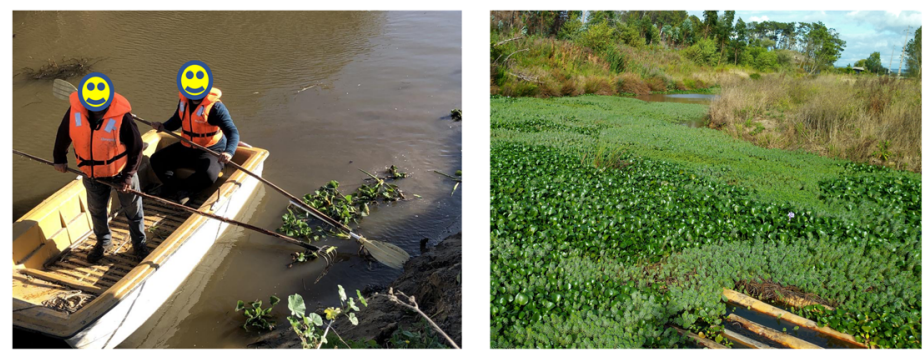

Fig. 1 Water hyacinth infestation in (a) lower Mondego valley and (b) Lis valley, center of Portugal.

Its emergent to free-floating nature makes water hyacinth a very effective competitor in newly invaded freshwater ecosystems. ${ }^{20}$ It outcompetes other aquatic plant species and forms dense, free-floating mats (Fig. 1), which in many instances completely cover freshwater surfaces, such as lakes, rivers, wetlands, and dams' reservoirs. ${ }^{15,21}$ Its presence and distribution dominate and suppress submersed vegetation, which are rooted plants with most of their vegetative mass below the water surface, and it outcompetes phytoplankton for nutrients and sunlight. ${ }^{22,23}$

The uncontrolled expansion of water hyacinth and the ubiquity of the subsequent eutrophication level in freshwater ecosystems are attributed to natural phenomena. ${ }^{24}$ Its excessive growth causes various environmental (including ecological and socioeconomic) impacts that are hazardous to aquatic systems and disable human uses of surface waters. ${ }^{25}$ It causes hypoxia, threatens freshwater quality and availability, ${ }^{3,8,26-29}$ worsens the quality of freshwater ecosystems, ${ }^{30}$ including the quality of the aquatic life, ${ }^{8,31,32}$ by causing changes in macroinvertebrate species richness ${ }^{33}$ and biodiversity loss, ${ }^{20,34,35}$ and promotes breeding grounds for pests and vectors. ${ }^{36,37}$

Moreover, the expansion of water hyacinth obstructs river flows and irrigation systems, ${ }^{38,39}$ thus increasing flood risk and hindering navigation ${ }^{40}$ and recreational water activities. A correct understanding of the spatiotemporal distribution and configuration of water hyacinth, which affect the impact of infestations, is therefore essential for effective management of water bodies, particularly in supporting river flood risk modeling. ${ }^{41}$ In addition, water hyacinth invasions choke dams' reservoirs and lakes. In places with hydroelectric dams, the invasion has led to damaged generators and coolers, resulting in the reduction of hydropower generation ${ }^{42,43}$ and threats to the electricity supply. ${ }^{44,45}$ Also, its biomass interferes with pumping stations for agricultural and domestic water supplies. ${ }^{46}$ The weed also reduces the flow of water through irrigation canals by $40 \%$ to $95 \%$ and promotes water loss through evapotranspiration.

The propagation of water hyacinth and the corresponding threat to freshwater ecosystems requires immediate attention; plant monitoring would make it possible to understand the spatial coverage of water bodies by water hyacinth and to adopt suitable management practices. However, the use of traditional field surveys and associated methods in monitoring water hyacinth infestations have proven costly, time-consuming, labor intensive, and limited in terms of spatial coverage..$^{21,48,49}$

The presence of water hyacinth in water bodies in Portugal, in the Sado River basin, ${ }^{50}$ was first reported in 1939, but it emerged also in other areas. Water hyacinth has reached its major expansion on the Tagus River basin, a problem that likely started in 1974; probable causes include the release of large amounts of plant mass from the Belver Lagoon. ${ }^{51}$ Nowadays, the infestation by water hyacinth is widespread in the central region of Portugal, whereas it seems that in the north of the country, the plant cannot survive due to its high sensitivity to low 
temperatures. ${ }^{50}$ This invasive plant became a problem in natural aquatic systems and agricultural hydraulic systems, such as Reserva do Paúl de Boquilobo, in the Golegã region, and the drainage and irrigation channels of the irrigated agricultural areas of the Tagus, Sado, Mondego, and Lis River basins (Fig. 1).

The main objectives of this research are to explore alternative methodologies to monitor and categorize the spread of water hyacinth and introduce new insights into the detection, observation, and mapping of invasive water hyacinth using vegetation and water indices calculated from multispectral remote sensing (RS) data from satellite Sentinel-2 (S2). This study focuses on a small water body located in the Mondego River (Portugal), which is part of the main drainage system of the lower Mondego agricultural area.

\section{Remote Sensing in Supporting Water Bodies Monitoring}

Particularly during the last decade, the increasing availability of open-source satellite data has created new possibilities for low-cost, large-scale monitoring of water bodies. ${ }^{52}$ Several studies show that satellite data have the ability to capture the spatial and temporal distribution of aquatic macrophytes using timely and cost-effective approaches. ${ }^{21,27,53}$ Furthermore, the continual coverage offered by satellite sensors provides spatial data for both short- and long-term monitoring, which are crucial for identifying and assessing the strengths and weaknesses of applied environmental management measures. ${ }^{54}$

RS techniques are economically effective and unconstrained by the size of water bodies or any other geographical barrier; corresponding data collection and analyses are far less timeconsuming than for other observational approaches used to inspect water bodies. Several studies discuss that multispectral RS tools are able to locate, identify, and provide enough details on the invasion level of alien plant species in time and space ${ }^{55-60}$ and assist in mapping and monitoring invasive weed outbreaks in certain ecosystems. ${ }^{61}$ Specifically, available medium spatial resolution sensors, e.g., Landsat 8 and S2, provide suitable data for monitoring hydrological components at a local scale. Such sensors are able to better detect the spatial distribution of invasive plant species and temporal dynamic changes in their incursion level, compared to classical ground-based surveys. ${ }^{53,62,63}$ Moreover, the frequent revisiting rates of satellite sensors provides long-term records that are useful to support decisions on the application of control measures, since the observations make it possible to assess the effectiveness of those measures. ${ }^{64,65}$ This information is valuable for governmental and environmental management agencies and decision makers, as well as for local communities.

To ensure the sustainability of regional or catchment scale monitoring of freshwater ecosystems, the development of sustainable methods to fight the spread of water hyacinth is critical. Given the spatial extent and the inaccessibility of some rivers and other water bodies, there is a pressing need to establish suitable technologies to assist in the geospatial characterization of this invasive species, offering appropriate spatial and temporal scales resolutions and monitoring skills. Multispectral RS seems to emerge as the primary data source for achieving this task with minimal costs. It provides operational tools that are cost-effective and can timely detect and map the spatial distribution and temporal dynamics of water hyacinth outbreaks across broad geographical areas. ${ }^{27,53} \mathrm{RS}$ datasets can be used in diverse ways, either to help identifying areas at risk, ${ }^{66}$ to enhance our understanding of the seasonal behavior of this invasive plant, to predict its spatial-time distribution or patchiness, ${ }^{67}$ and to quantify its ecological and hydrological impacts.

The majority of the existing studies have focused on mapping water hyacinth in large water bodies (e.g., lakes and reservoirs), whereas studies focusing on small rivers are scarce. However, the latest developments in RS technology offer new perspectives and benefits for detecting and mapping the spatiotemporal distribution of water hyacinth in small water bodies, ${ }^{9}$ which will assist in the assessment, management, and follow up of this environmental problem in such type of water systems. Current RS technology provides opportunities to map and quantify the wider riverscape (i.e., water, sediment, and vegetation) at an unprecedented spatiotemporal resolution that can support several applications, such as fluvial geomorphology, riparian vegetation, and flood risk management. ${ }^{68,69}$ Unlike the broadband multispectral data, improved spectral and spatial resolution sensors, such as the recently launched 10-m spatial resolution S2 multispectral 
instrument (MSI), have significantly enhanced research capabilities and the understanding of the spatial distribution of water hyacinth, especially in small freshwater bodies, which scale of interest has been so far beyond the reach of the typical larger resolution of the broadband multispectral sensors. The S2 MSI sensor is thus contributing greatly to detecting, mapping, and monitoring water hyacinth infestation and coverage at a river scale. ${ }^{9,70}$

Vegetation indices (VI) calculated from different spectral bands (obtained by distinct remote sensors) have been tested in mapping the spatial distribution of water hyacinth. ${ }^{21,27,59,63,71-73}$ Particularly, multitemporal data allow that the normalized difference vegetation index (NDVI), which positively correlates with plants' health or vigor, i.e., plants exhibiting concentrated green pigments or active photosynthetic rates, is used to monitor infestations of water hyacinth; its signal relates to a prominent level of reflectance in the near-infrared (NIR) spectral band. ${ }^{64,65}$

\section{Materials and Methods}

\subsection{Study Area}

The selected study area $\left(36^{\circ} 56^{\prime} 39^{\prime \prime} \mathrm{N} ; 10^{\circ} 22^{\prime} 39^{\prime \prime} \mathrm{W}\right)$ is a stretch of the old/abandoned bed of the Mondego River (Fig. 2), known as old Mondego River, located near the village of Ereira (Montemor-o-Velho, Portugal). This water body, which integrates the local drainage system, suffers currently from water hyacinth infestation. In the downstream end of this drain, where it joins the Foja River, there is a drainage pumping station (Foja Pumping Station). This pumping station discharges to the main bed of the Mondego River; its presence gives protection against the entry of brackish waters into the Foja River and the old Mondego Riverbranch. Also its operation is crucial for preventing the flooding of the neighboring agricultural lands and small villages (Fig. 2), in case of high-water levels.

According to the Köppen-Geiger climate classification, the climate in the study area is temperate with dry and mild summers (Csb). ${ }^{74}$ For the period 1971 to 2000 , data from the nearest weather station ${ }^{75}$ reveal that the area's mean monthly precipitation varied between $128.9 \mathrm{~mm}$ in December and $9.6 \mathrm{~mm}$ in July; daily average temperature ranged from $9.7^{\circ} \mathrm{C}$ in winter to $20.8^{\circ} \mathrm{C}$ in summer (Fig. 3).

In recent years, mainly during summer, water hyacinth is strongly found in the old Mondego river, transforming the river channel between the village of Ereira and the Foja Pumping Station into an immense and thick green "carpet" (Fig. 4). Although local temperatures are lower than the water hyacinth optimum growth temperature $\left(25^{\circ} \mathrm{C}\right.$ to $\left.30^{\circ} \mathrm{C}\right){ }^{76}$ this plant manages to grow and invade the old Mondego river. Also while it is known that this invasive plant is rather sensitive to high-water salinity, the Foja Pumping Station acts as a barrier for the intrusion of brackish water from the main bed of the Mondego River into these water courses, giving ground for favorable growth conditions of the plant.
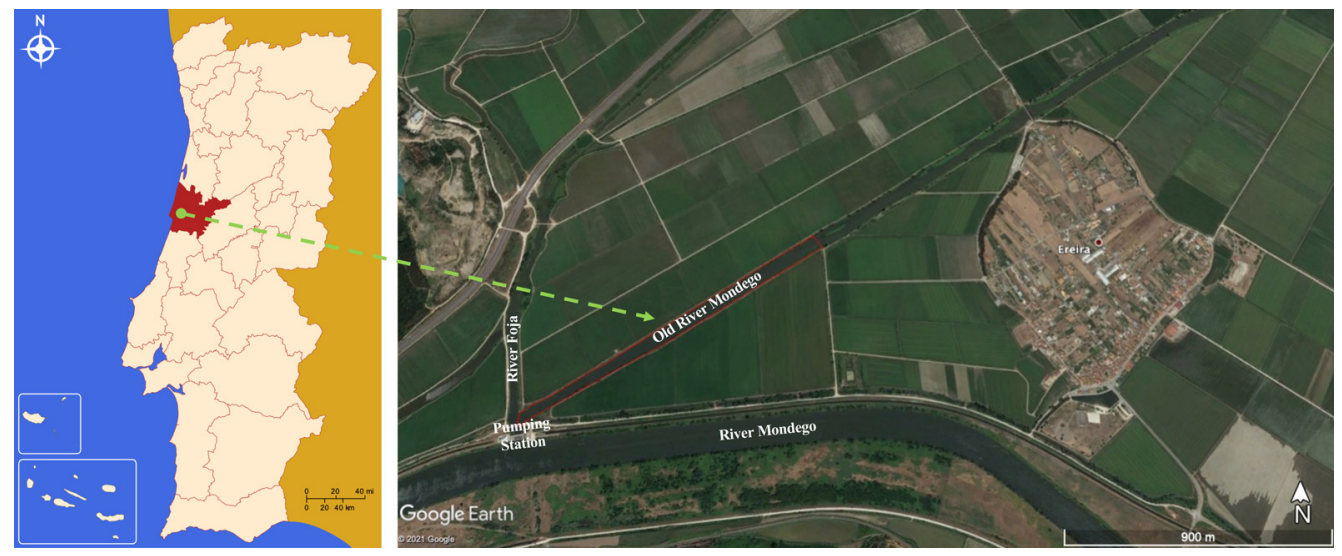

Fig. 2 Location of the study area (red box) in the downstream stretch of the old Mondego River and the Foja Pumping Station, near the village of Ereira (Montemor-o-Velho, Portugal). 


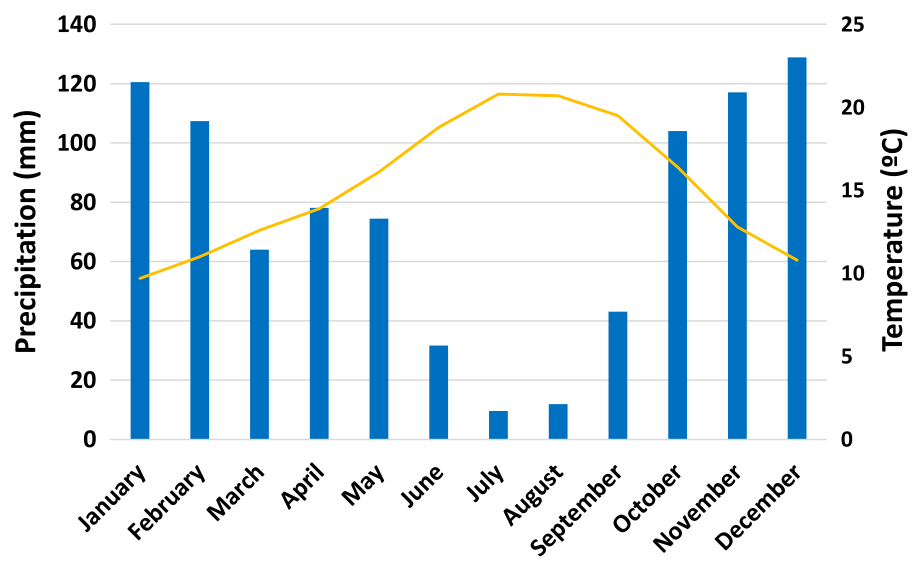

Average monthly precipitation - Average daily temperature

Fig. 3 Average daily temperature and average monthly precipitation in Montemor-o-Velho (Portugal) during the period 1971 to 2000. Data were reported by Instituto Português do Mar e da Atmosfera. ${ }^{75}$

(a)

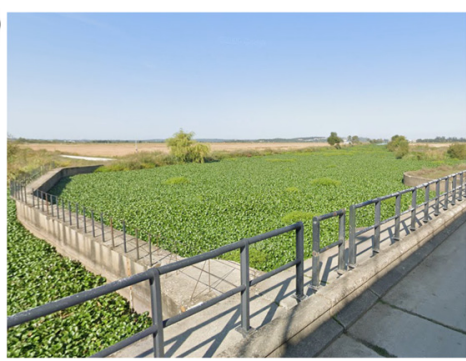

(b)

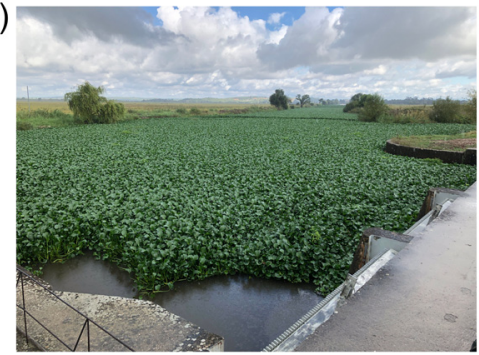

Fig. 4 Accumulation of water hyacinth in the old Mondego river, near the Foja Pumping Station (Portugal) in (a) September 2019 (Google Street View 2021) and (b) September 2021.

As expected, the strong variability in the rainfall input ${ }^{77}$ influences runoff and river flows; it, therefore, also influences the water flowing in the old Mondego river, which in turn impacts the water hyacinth distribution along the river channel, since high flows force the downstream movement of the water hyacinth plants.

The recurrent presence of this invasive plant in this water body, mainly near the Foja Pumping Station (Fig. 5), creates severe and harmful problems, not only in the summer but also

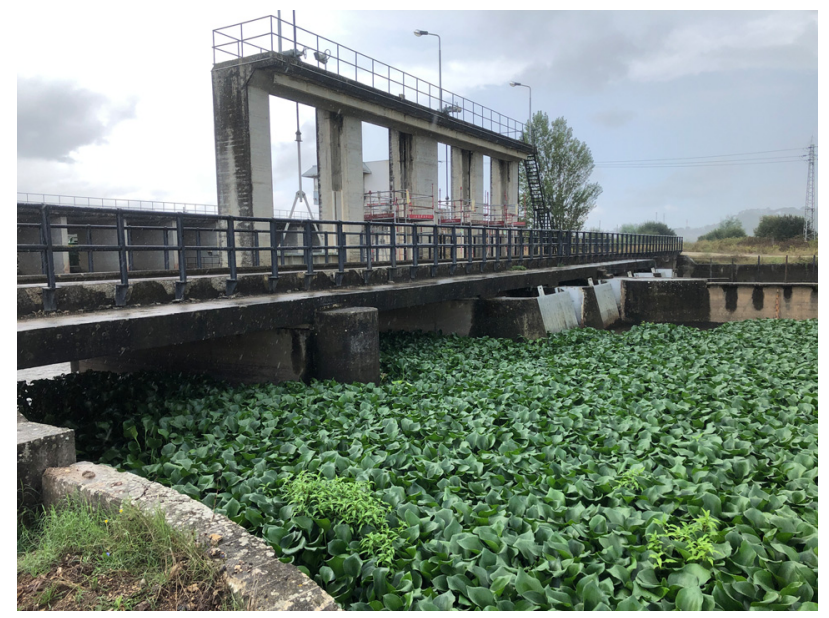

Fig. 5 Water hyacinth infestation near the Foja Pumping Station in Portugal (September 2021). 
during the winter. On the one hand, the presence of water hyacinth reduces the flow capacity of water courses. And, on the other hand, the pumping station is littered with water hyacinth and debris, which strongly hinders its operation and the necessary drainage of the water from both the Foja River and the old Mondego river.

A main consequence is the flooding of the village of Ereira and nearby agricultural areas. Due to the flood protection works carried out in the main bed of the Mondego River in the 1980s, and the proximity to the Atlantic Ocean that affects the water levels in the river (i.e., tidal effect), ${ }^{78}$ the operation of this pumping station as part of this area's drainage system is of utmost importance: discharge by gravity is limited. Overall, the presence of water hyacinth in this area is not yet fully understood, which hinders the application of efficient measures to deal with this environmental and socioeconomic problem.

\subsection{Data Sets and Preprocessing}

RS data from satellites' platforms have been increasingly incorporated in studies dedicated to improving the knowledge on the environment and used for environmental operational management purposes. A common application is the calculation of indices based on the opportunity given by this technology to capture spectral signals at spatial and temporal scales of interest across a range of applications. Examples of such spectral indices are vegetation and water indices.

The different vegetation reflectance bands' data that are obtained from RS platforms, especially those that rely on the red, green, and NIR wavelength bands, are used to calculate indices that are effective in assessing different attributes of plants at the image's pixel scale, which is determined by the characteristics of reflectance. Vegetation reflectance is low in both the blue and red regions of the visible spectrum, it peaks locally in the green region, and it is highest in the NIR range. Thus, by algebraically combining these bands in calculating VI, different spectral signatures are enhanced for different vegetation properties.

Thirty images (ortho-images in Universal Transverse Mercator/World Geodetic System-84 projection) extracted from S2 MSI RS 10-m spatial resolution data, which cover the entire study area, were used in this study; these images had $<8 \%$ of clouds, however, they all offered cloud free views of the study area (thus no masking was applied). The images were downloaded from the online Sentinel Copernicus data hub ${ }^{79}$ and were acquired from the top of atmosphere reflectance MSI SA and S2B L1C files from the European Space Agency. Revisiting rate is about 5 days.

\subsection{Methodology}

The methodology used in this study to monitor and categorize the spread of the invasive water hyacinth plant is founded on the calculation of vegetation and water indices based on RS data (Sec. 3.2) and their analyses. Thus, the presence of the water weed will be supported by the calculation of the NDVI for studying the distribution of the plant in a selected water course and the normalized difference water index (NDWI) for assessing the free surface of the water body. These normalized indices are defined in Table 1 and take values between -1.0 and +1.0 ; both indices are derived using similar principles.

Table 1 Description of the satellite-derived indices NDVI and NDWI, calculated from multispectral wavelength bands. For S2, bands' spectral resolution (central wavelength) is: band 4 (665 nm), band $8(842 \mathrm{~nm})$, band $8 \mathrm{a}(865 \mathrm{~nm})$, and band $11(1610 \mathrm{~nm})$.

\begin{tabular}{|c|c|c|c|c|c|}
\hline Index & Abbreviation & Equation & $\begin{array}{l}\text { Formula using } \\
\text { S2 bands }\end{array}$ & Attributes assessed & References \\
\hline $\begin{array}{l}\text { Normalized } \\
\text { difference } \\
\text { vegetation index }\end{array}$ & NDVI & $\frac{\text { NIR }- \text { red }}{\text { NIR }+ \text { red }}$ & $\frac{\text { Band }_{8}-\text { band }_{4}}{\text { band }_{8}+\text { band }_{4}}$ & $\begin{array}{l}\text { Biomass, canopy } \\
\text { structure, leaf area, } \\
\text { and chlorophyll content }\end{array}$ & $\begin{array}{l}\text { Rouse Jr. } \\
\text { et al., } 1974^{80}\end{array}$ \\
\hline $\begin{array}{l}\text { Normalized } \\
\text { difference } \\
\text { water index }\end{array}$ & NDWI & $\frac{\mathrm{NIR}-\mathrm{SWIR}}{\mathrm{NIR}+\mathrm{SWIR}}$ & $\frac{\text { Band }_{8 a}-\text { band }_{11}}{\text { band }_{8 a}+\text { band }_{11}}$ & $\begin{array}{l}\text { Plant nitrogen content } \\
\text { and surface waters }\end{array}$ & $\begin{array}{l}\text { McFeeters, } \\
1996^{81}\end{array}$ \\
\hline
\end{tabular}


The NDVI is frequently used in agriculture, in particular to detect live green plant canopies, thus, displaying greenness. Its calculation is supported by the characteristics of two spectral bands: absorption of the chlorophyll pigment in the red spectral band (0.62 to $0.69 \mu \mathrm{m})$ and the high reflectance of plant materials in the NIR band $(0.75$ to $1.3 \mu \mathrm{m})$. Since high photosynthetic activity leads to lower values of reflectance coefficients in the red region of the spectrum and large values in the NIR region of the spectrum, the ratio between these indicators (Table 1) allows to clearly separate the vegetation from other natural objects. Thus NDVI is directly related to the plants' photosynthetic capacity and hence energy absorption of plant canopies. As a result of the spectral analysis, this index has the potential to assess canopy growth or vigor and the density of vegetation. Within the value range of NDVI: (i) higher positive values indicate peak growth rates of live plants whereas lower positive values may reveal the existence of unhealthy plants; (ii) values around zero ( -0.1 to 0.1 ) generally correspond to barren areas (e.g., rock and sand) or dead plants; (iii) negative values, approaching -1 , correspond to water. ${ }^{64}$ One limitation in this index is that it shows low sensitivity to detect minor differences in high chlorophyll content and biomass, which is known as "saturation effect;" $" 82,83$ saturation occurs when NDVI is applied to images over areas having dense vegetation, i.e., when the level of the leaf area index (LAI) becomes high (i.e., LAI $\geq 3$ ). ${ }^{82}$

The NDWI is usually used to delineate open water bodies and features and enhance their presence in remotely sensed digital imagery. The selection of the wavelengths used in NDWI (Table 1) maximizes the reflectance properties of water. ${ }^{84}$ That is: (i) it maximizes the typical reflectance of water features using green or short-wave infrared (SWIR) band wavelengths; (ii) it minimizes the low reflectance of NIR by water features; and (iii) it maximizes the high reflectance of NIR by vegetation and soil features. As a result, water features are enhanced by NDWI positive values, whereas null or negative NDWI values reveal the presence of vegetation and soil. Although the use of NDWI is found pertinent to studying water hyacinth covers over open water surfaces (OWSs), complementary to the NDVI analysis. Moreover, since NDWI varies almost linearly with liquid water thickness,${ }^{81}$ it is, therefore, a relevant proxy for plant water stress and changes in surface water. ${ }^{85,86}$

Calculation of NDVI based on S2 data (Sec. 3.2) used bands 4 and 8 and calculation of NDWI used bands 8A and 11 (Table 1). The Quantum Geographic Information System (QGIS 3) software was used to delimit the study area and calculate the NDVI and the NDWI for the data collected, including basic descriptive statistics.

Fusilli et al. ${ }^{87}$ estimated the aquatic vegetation cover in Lake Victoria based on the scaling of the NDVI; the method used assumes the separation of floating vegetation (FV) from sparsesubmersed vegetation (SMV) and OWS, by applying suitable NDVI threshold values: values $<0.4$ were used to discriminate $\mathrm{FV}$, values between 0.2 and 0.4 to identify SMV, and values lower than 0.2 to assess OWS. In this study, the same method was used aiming at the increased understanding of the water hyacinth infestation and coverage in the study area.

Complementary, the spectral water index NDWI was applied to the study area to identify water and nonwater surfaces. The separation between water and nonwater objects is allowed since free water surface areas generally have NDWI values $>0$, whereas vegetation areas have strong NDWI negative values. Thus the NDWI images' classification into water and nonwater surfaces uses a NDWI threshold of zero. ${ }^{81}$

An overview of the different stages of the methodology applied in this study is shown in the simplified flowchart in Fig. 6.

\section{Results and Discussion}

\subsection{Analyses of Sentinel-2 Data: NDVI and NDWI}

For the exploratory appraisal of the recurrent presence of the water hyacinth invasive plant in the study area, the NDVI and NDWI were inspected for the period 2017 to 2021 (Fig. 7); the data concern a selected point (i.e., pixel, centered $40^{\circ} 8^{\prime} 55.22^{\prime \prime} \mathrm{N} ; 8^{\circ} 44^{\prime} 9.98^{\prime \prime} \mathrm{W}$ ) in the old Mondego River branch, in the vicinity of the Foja Pumping Station. The annual water hyacinth cycle of blooming, dominance, and decline is clearly shown in Fig. 7. The water hyacinth invasion and 


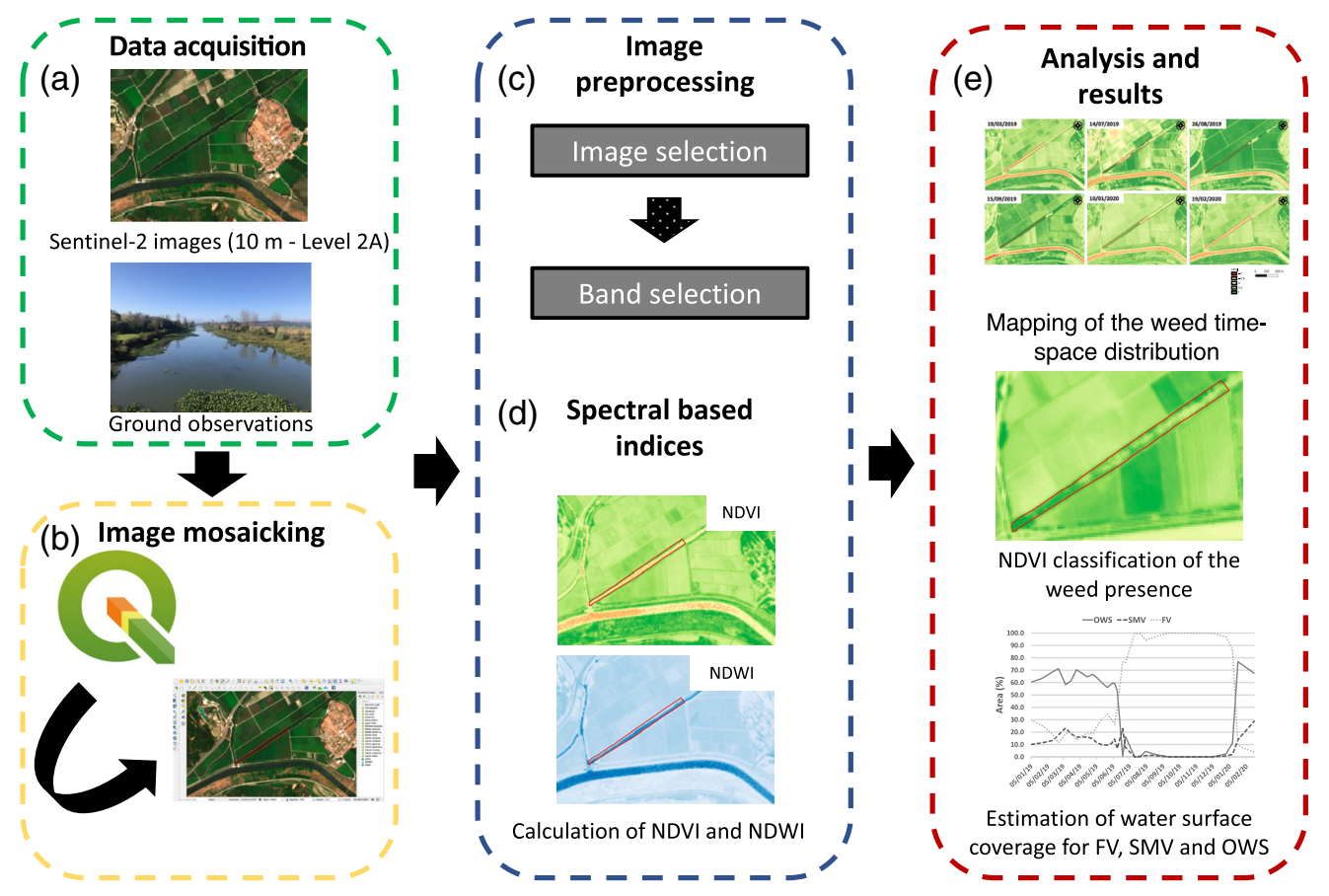

Fig. 6 Simplified flowchart of the methodology used in this study.

corresponding high dominance in terms of water surface coverage is manifested by the higher NDVI values and, correspondingly, by the lower NDWI values. The decline in the presence of water hyacinth has been observed to be strongly linked to high flows that carry downstream the invasive weed found in the water course.

However, two situations can be highlighted in Figs. 7(a) and 7(b), corresponding to the water hyacinth "long" cycle in 2017 and "short" cycle in 2020, which are manifested by the NDVI and NDWI curves. It is noted that 2017 was an exceptionally warm year (the second warmest year since 1931), which was also extremely dry (it is among the four driest years since 1931); annual precipitation was about $60 \%$ of mean annual precipitation. ${ }^{88}$ The persistent marked precipitation anomaly was reduced in December 2017, but the drought situation continued, although with less severity. This could explain the particular NDVI behavior that traduces, namely, the dominant presence of water hyacinth in the study area during a longer period (i.e., the longer "plateau" in the NDVI curve for 2017), compared to other years, and the two-phase drop in the NDVI curve [Fig. 7(a)].

On the other hand, the situation revealed by the NDVI curve for 2020 has instead anthropogenic origin: the local government decided to clean up the old river channel between Ereira and the Foja Pumping Station, which significantly reduced in 2020 the presence of water hyacinth in the study area [see the shorter 2020's "plateau" in the NDVI curve, in Fig. 7(a)]. Nevertheless, the infestation problem was not solved, since the presence of water hyacinth was re-established in the following favorable growth period of the plant, similar to previous years. Note that the NDVI and NDWI curves (Fig. 7) are roughly mirror images of each other, and that the former comments apply also, reversely, to the NDWI curve, i.e., its analysis confirms the profuse presence of the vegetation cover by water hyacinth in the water surface of the sampled area, over time.

Note, moreover, that the strong NDVI and NDWI signal fluctuations in Fig. 7 are likely related to variations in water inflow in this canal and changes in the water surface; these changes are influenced by the rainfall-runoff process (thus, by the variability in surface flows) and the impact of high discharges in forcing the invasive plants to relocate. This explanation is supported further by the overall intra-annual NDWI behavior that resembles the average pattern of annual precipitation distribution shown in Fig. 3 and, thus, also likely that of surface runoff.

For pursuing the detailed characterization of the behavior of the water hyacinth invasive plant found in the open water course selected, the NDVI and NDWI were calculated from S2 images 
(a)

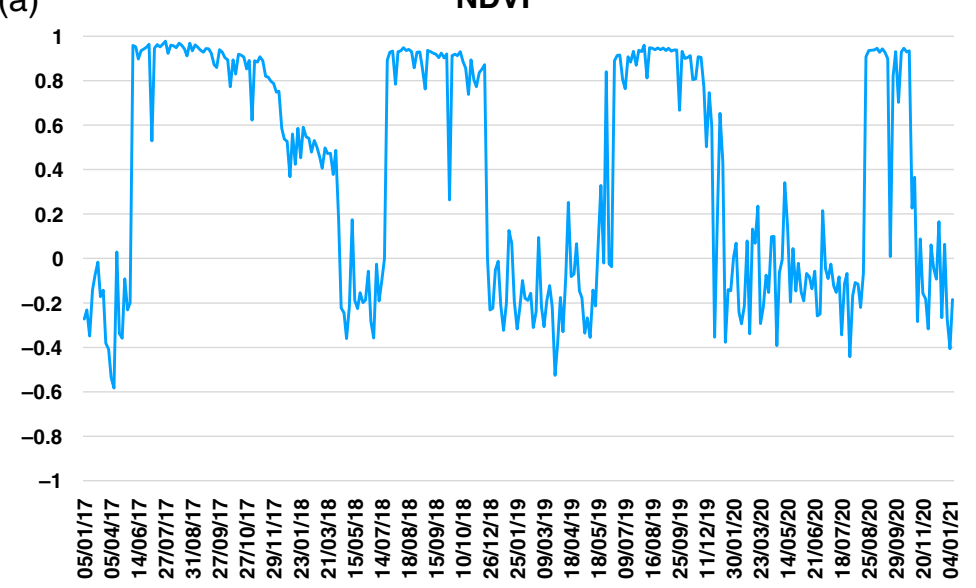

(b)

NDWI

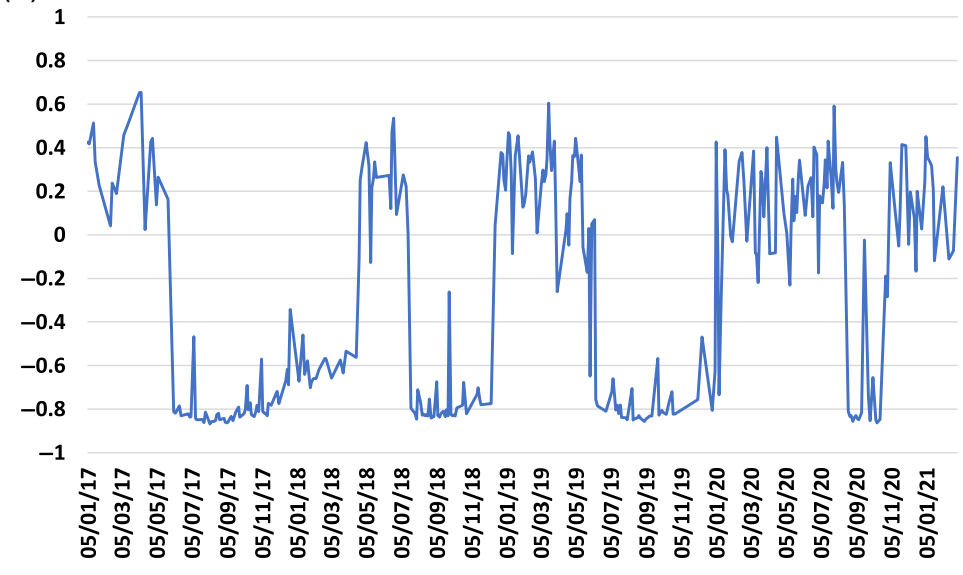

Fig. 7 Temporal variation of the presence of water hyacinth near the Foja Pumping Station (lower Mondego valley, Portugal), for the period 2017 to 2021, assessed using (a) NDVI and (b) NDWI (data source: Sentinel Hub EO Browser, 2021).

for the period between January 2019 and February 2020, for a given sample area identified along a water course (Fig. 2). This area comprises a 1-km long stretch of the old Mondego river and covers $\sim 6.5 \mathrm{ha}$; it is located immediately upstream of the Foja Pumping Station. The increase in the sampled area, in relation to the data in Fig. 7, led to a decrease in the availability of multitemporal data, which follows from a reduction roughly from 60 to 30 images.

The selected NDVI images shown in Fig. 8 clearly reveal the presence of the water hyacinth in the studied water course (old Mondego river) and changes over time in this weed coverage in 2019/2020. The NDVI scale used in the maps in Fig. 8 applies a red-yellow-green palette to the NDVI-processed imagery, which is generally seen as more intuitive than other options: green signals healthy vegetation and red highlights areas lacking vegetation. In comparison to other satellites, the improved resolution of S2 allows for the more precise definition of surface details and makes NDVI a very useful index also for the study of small objects, such as small water courses. The study area is covered by 645 pixels.

Analysis of the multitemporal satellite data (Fig. 9) for this area indicates a rapidly increasing boost in the average NDVI at the beginning of summer, which reveals a strong outburst of water hyacinth and that this incursion of the invasive plant pertained until the second half of wintertime, when the NDVI also decreased abruptly. Average NDVI values varied from $-0.08 \pm 0.27$ to $0.91 \pm 0.05$, during the study period. Negative NDVI values and values close to zero indicate the presence of water surfaces. The highest NDVI values reveal that roughly from August to December 2019 the surface of the study area was massively covered by water hyacinth. This can also be observed in Fig. 8 . 

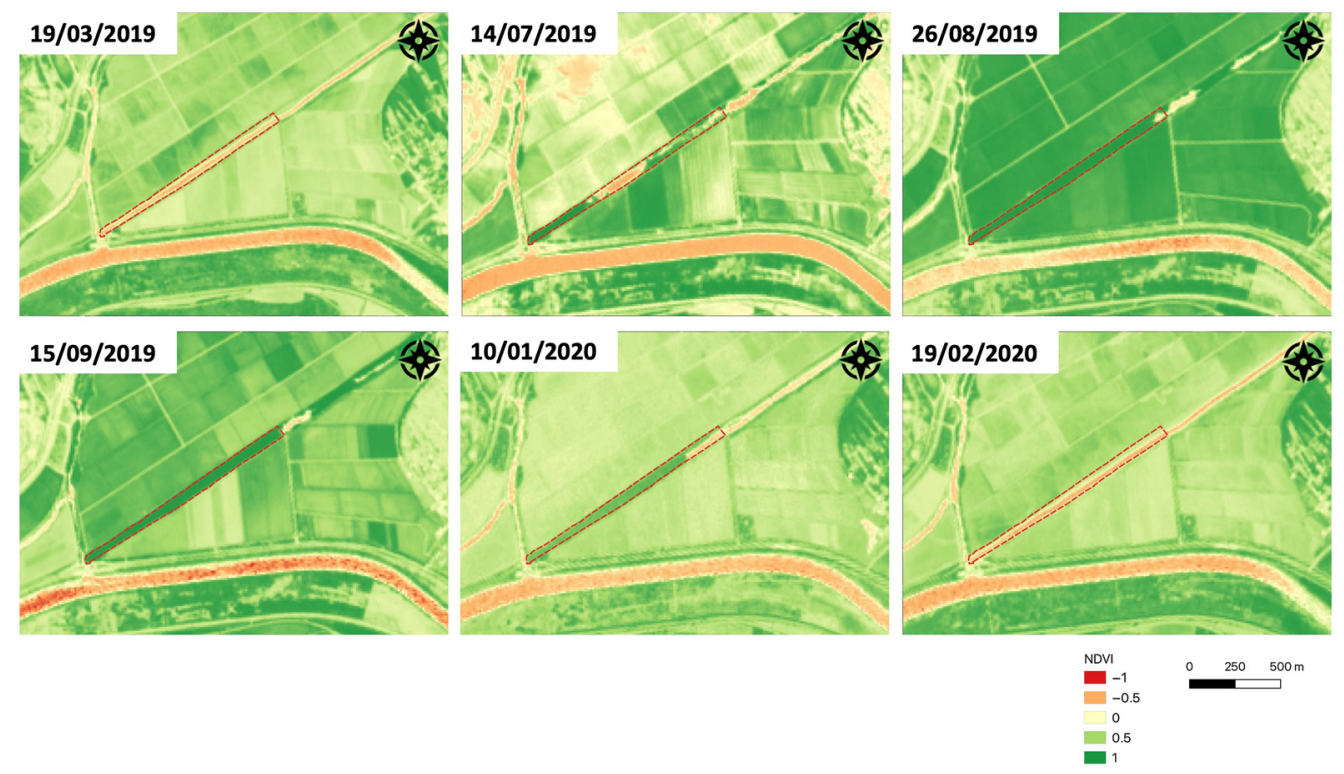

Fig. 8 NDVI maps illustrating the spatial distribution of water hyacinth in the study area (check the red box, along the old Mondego river) and showing the situation in the selected and nearby water courses, between March 2019 and February 2020. The mapping applies a red-yellow-green palette to the NDVI-processed imagery: green signals healthy vegetation and red highlights areas lacking vegetation.

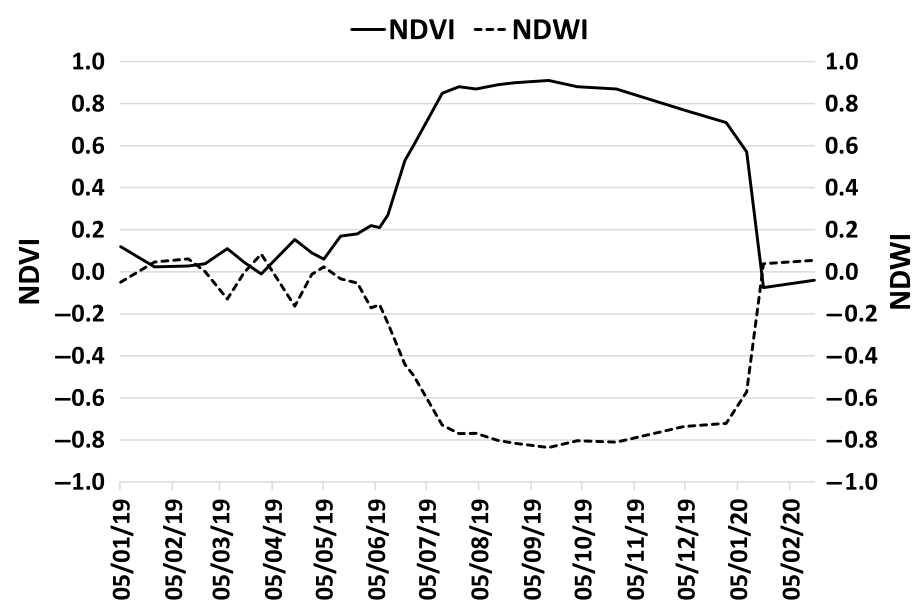

Fig. 9 Average NDVI and NDWI time series for the selected river branch study area, revealing the intensity of the water hyacinth coverage in the selected stretch of the old Mondego river (Portugal) between January 2019 and February 2020.

Complementary to the analysis of NDVI, the NDWI also contributed to investigate the presence of water and nonwater surfaces in the study area. Results in Fig. 9 show that average NDWI values, which varied between $-0.84 \pm 0.04$ and $0.09 \pm 0.32$ during the study period, dropped markedly in the beginning of the summer due to the rise of the water hyacinth's surface percentage cover in the water course, and increased again pronouncedly in the end of January 2020. This result agrees with the finding that emerged from the analysis of NDVI.

The concurrent analysis of the two indices, NDVI and NDWI, illustrates that, in relation to NDVI, the presence of vegetation enhances the magnitude of this index, whereas the presence of open water features suppresses it because of the different ways in which these features reflect the red and NIR bands wavelengths. When/if the equation is reversed and the green band is used instead of the red band, as for NDWI (see Table 1), then the outcome for NDWI would also be reversed, i.e., the signal for vegetation is suppressed and for open water features is enhanced: 
water features lead to positive NDWI values while vegetation leads to zero or negative values. ${ }^{81}$ Thus for the study area, the sudden drop to negative and low NDWI values (Figs. 7 and 9) and the period when such negative values are maintained correspond to the periods when, respectively, NDVI values increased and large NDVI values were maintained. This finding confirms the presence of high water hyacinth coverage in the water course during several months during the year.

Comparison of Figs. 7 and 9 also illustrates: (i) the effect of smaller sampling frequency in describing the time variability (here, related to the data availability) and (ii) the smoothing effect that results from spatial averaging over larger scales (i.e., from the pixel to the study area scale). In particular, it is noticeable the different ranges of NDVI and NDWI values attained for the cases reported in Figs. 7 and 9: average NDVI and NDWI values in Fig. 9 are for the study area (6.5 ha), whereas the data in Fig. 7 are for the conditions in the one single pixel illustrated (10-m resolution).

\subsection{Mapping of the Spatial Distribution of Water Hyacinth Using NDVI}

The scaling of the NDVI in the study area was assessed based on $30 \mathrm{~S} 2$ images, using the methodology proposed by Ref. 87 that was described in Sec. 2.2. The results in Fig. 10 show that the FV component identified for the water hyacinth started to increase between May and June 2019, but that the growth rapidly speeded up in the beginning of July; the area covered by the invasive plant stayed almost stable during a long period of time, of several months, and only decreased in the middle of winter. The observed sudden drop in NDVI (thus the drop in the presence of water hyacinth) is found to be explained by the higher amount of water that usually flows through the river channel during the rainy season (triggered by high-intensity rainfall events) and not by the relatively slow drop in air temperature (Fig. 3). The SMV component remained relatively more constant during the study period, except during the period of summer until winter, where it drops to zero; this occurs due to the growth of the water hyacinth plant and the dominance of the overwater plant mass, which has been progressively included in the FV component during that period. The behavior manifested by the surface coverage corresponding to the OWS component was rather opposite to that of FV, i.e., OWS is negatively correlated with FV.

Several studies documented that the use of RS is more accurate on emergent and floating aquatic vegetation mapping than submersed aquatic vegetation. ${ }^{89,90}$ Submersed macrophytes have been reported to be distinguished more clearly by their lower absolute reflectance in the NIR, whereas other narrow hyperspectral channels are used to discriminate species on the basis of leaf optical properties and other biophysical or biochemical properties ${ }^{63,91}$ This discussion is beyond the scope of this work.

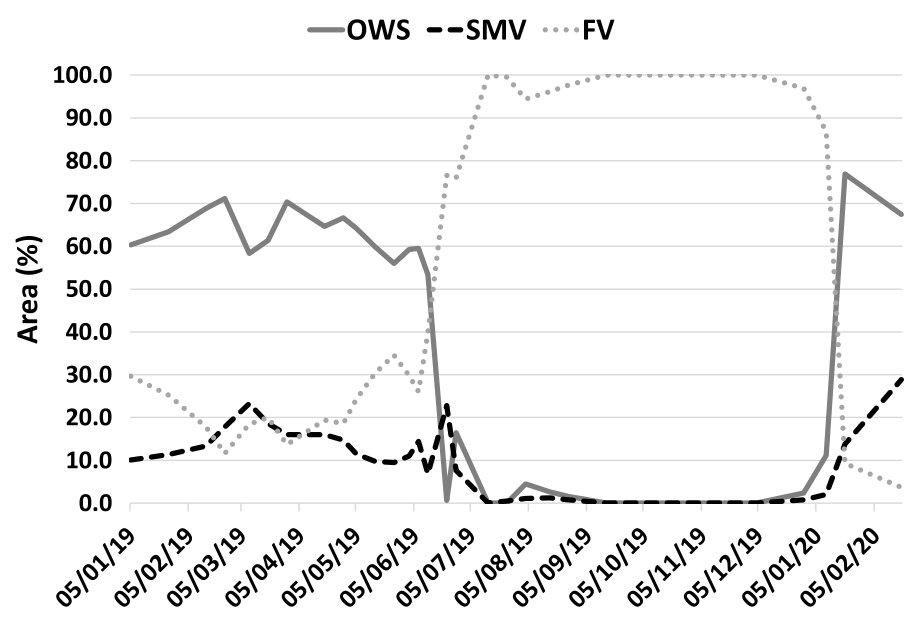

Fig. 10 Spatial and temporal variation of water hyacinth coverage in the selected stretch of the old Mondego river (Portugal), during 2019/2020, assessed by NDVI classification. Total studied area covers $\sim 6.5$ ha. Estimates of the percentage area coverage of the water surface are for FV $(\mathrm{NDVI} \geq 0.4)$, SMV $(0.2<\mathrm{NDVI}<0.4)$, and OWS $(\mathrm{NDVI} \leq 0.2)$. 


\section{Conclusions}

Water hyacinth has substantial negative impacts on hydrology, socioeconomics, and aquatic ecosystems. This invasive aquatic weed has spread to almost all continents, and it affects water bodies in the Iberian Peninsula, in southern Europe; the situation in the downstream part of Mondego River (Portugal) is investigated in this study.

Results confirm that S2 MSI RS data has the potential to investigate the distribution of water hyacinth in small rivers, over time and across a defined area. They also suggest that scaling of this weed coverage based on NDVI classifiers is suitable for quantitative analysis due to the typical singularity of the vegetation cover of the water surface established by water hyacinth, especially in small water bodies.

Furthermore, it is expected that the approach used to assess the spatiotemporal distribution of water hyacinth based on RS data, and findings, might contribute to open new avenues in scientific research focusing on the modification of freshwater bodies, and on the impact of climate change and anthropogenic activities surrounding open water systems.

Although this study focuses on a small water body located in the lower Mondego valley (Portugal), in the neighboring Lis River basin (located to the south of the Mondego basin), the water hyacinth is also a threat to local hydraulic structures of the drainage system of the Lis Valley irrigation district, and performance of its infrastructures. However, the resolution of the available RS data hinders so far, the applicability of the proposed methodology to the Lis case study due to the smaller size of the water courses found in the Lis area. Overall, the unbalance between the scale of interest and the scale of observation available at the moment may introduce an unquantifiable bias in results. This issue will be addressed further in future research. It is also expected that technology developments will soon make available RS data of high enough resolution to deal with very small water courses, and that this scale issue will soon be overcome.

It is expected that these findings are helpful for managers and decision makers in defining and implementing appropriate strategies for monitoring and controlling the water hyacinth blooming and invasion of small rivers and lakes, and other larger water bodies. In particular, the opportunity for the early eradication (e.g., by mechanical methods) of the invasive plant could be more easily assessed and planned making use of available and valuable RS information from satellite platforms. Although water hyacinth infestations' preventive strategies are best, once water bodies are infested, integrated measures are recommended to manage the aquatic weed.

\section{Acknowledgments}

The research described in this paper was supported by the Fundação para a Ciência e a Tecnologia under Grant No. PRIMA/0006/2018 (Project MEDWATERICE: toward a sustainable water use in Mediterranean rice-based agro-ecosystems), with the support of PRIMA Program (PRIMA-Section-2018; Topic: 1.1.3: Irrigation technologies and practices), and by the European Agricultural Fund for Rural Development (FEADER) under Grant No. PDR2020-1.0.1FEADER-030913 (project Grupo Operacional para a Gestão da Água no Vale do Lis), through the Acordo de Parceria Portugal 2020, Programa PDR2020, Medida Inovação, Submedida/Ação Inovação, and Intervenção Grupos Operacionais. The authors have no relevant financial interests in the manuscript and no other potential conflicts of interest.

\section{Code, Data, and Materials Availability}

Publicly available datasets were analyzed in this study and support reported results. Those datasets can be found in Copernicus Open Access Hub at https://scihub.copernicus.eu. Further inquiries about the data can be directed to the corresponding author.

\section{References}

1. W. T. Penfound and T. T. Earle, "The biology of the water hyacinth," Ecol. Monogr. 18, 447-472 (1948). 
2. GISD-Global Invasive Species Database, “Eichhornia crassipes (aquatic plant)," International Union for the Conservation of Nature (IUCN), Gland, Switzerland, 2006, http://www .issg.org/database/species/ecology.asp? $\mathrm{Si}=70$ (accessed 20 August 2021).

3. M. P. Hill and J. A. Coetzee, "Integrated control of water hyacinth (Eichhornia crassipes) in Africa," EPPO Bull./Bull. OEPP 38(3), 452-457 (2008).

4. M. G. Dersseh et al., "Water hyacinth: review of its impacts on hydrology and ecosystem services-lessons for management of Lake Tana," Chapter 19 in Extreme Hydrology and Climate Variability, A. M. Melesse, W. Abtew, and G. Senay, Eds., pp. 237-251, Elsevier (2019).

5. L. G. Holm et al., The World's Worst Weeds: Distribution and Biology, Krieger Publishing Company, Malabar, Florida (1991).

6. L. A. Navarro and G. Phiri, Water Hyacinth in Africa and the Middle East: A Survey of Problems and Solutions, International Development Research Centre, Ottawa (2000).

7. M. H. Julien, "Biological control of water hyacinth with arthropods: a review to 2000," in ACIAR Proc. 102, M. H. Julien et al., Eds., pp. 8-20 (2001).

8. J. M. Mironga, J. M. Mathooko, and S. M Onywere, "Effects of spreading patterns of water hyacinth (Eichhornia crassipes) on zooplankton population in Lake Naivasha, Kenya," Int. J. Sustain. Dev. 3(10), 1971-1987 (2014).

9. K. H. Thamaga and T. Dube, "Remote sensing of invasive water hyacinth (Eichhornia crassipes): a review on applications and challenges," Remote Sens. Appl. 10, 36-46 (2018).

10. T. Téllez et al., "The water hyacinth, Eichhornia crassipes: an invasive plant in the Guadiana River Basin (Spain)," Aquat. Invas. 3, 42-53 (2008).

11. B. Gopal, Water Hyacinth, Elsevier Science Publishers, Amsterdam (1987).

12. W. T. Parsons and E. G. Cuthbertson, Noxious Weeds of Australia, CSIRO Publishing, Collingwood (2001).

13. D. J. Kriticos and S. Brunel, "Assessing and managing the current and future pest risk from water hyacinth, (Eichhornia crassipes), an invasive aquatic plant threatening the environment and water security," PLoS One 11(8), e0120054 (2016).

14. C. S. Owens and J. D. Madsen, "Low temperature limits of waterhyacinth," J. Aquat. Plant Manag. 33, 63-68 (1995).

15. A. Malik, "Environmental challenge vis a vis opportunity: the case of water hyacinth," Environ. Int. 33, 122-138 (2007).

16. S. Tiwari, S. Dixit, and N. Verma, "An effective means of biofiltration of heavy metal contaminated water bodies using aquatic weed Eichhornia Crassipes," Environ. Monit. Assess. 129, 253-256 (2007).

17. S. Patel, "Threats, management and envisaged utilizations of aquatic weed Eichhornia crassipes: an overview," Rev. Environ. Biotechnol. 11, 249-259 (2012).

18. J. E. Havel et al., "Aquatic invasive species: challenges for the future," Hydrobiologia 750, 147-170 (2015).

19. R. P. Keller and D. M. Lodge, "Invasive species," in Encyclopedia of Inland Waters, G. E. Likens, Ed., pp. 92-99, Academic Press, New York (2009).

20. P. Pyšek and D. M. Richardson, "Invasive species, environmental change and management, and health," Аnnu. Rev. Environ. Resour. 35(1), 25-55 (2010).

21. M. Shekede, S. Kusangaya, and K. Schmidt, "Spatio-temporal variations of aquatic weed abundance and coverage in Lake Chivero, Zimbabwe," Phys. Chem. Earth Parts A/B/C 33, 714-721 (2008).

22. D. S. Mitchell, "African aquatic weeds and their management," in The Ecology and Management of African Wetland Vegetation, Geobotany, P. Denny, Ed., Vol. 6, pp. 177202, Springer, Dordrecht (1985).

23. R. Roijackers, S. Szabo, and M. Scheffer, "Experimental analysis of the competition between algae and duckweed," Arch. Hydrobiol. 160, 401-412 (2004).

24. R. Law, "Fisheries-induced evolution: present status and future directions," Mar. Ecol. Prog. Ser. 335, 271-277 (2007).

25. S. Chander et al., "Growth of invasive aquatic macrophytes over Tapi river," in The Int. Arch. Photogramm. RS and Spatial Inf. Sci., Proc. ISPRS TC V Mid-term Symp. Geospatial Technol.-Pixel to People, Dehradun, Vol. XLII-5 (2018). 
26. P. E. Ndimele, C. A. Kumolu-Johnson, and M. A. Anetekhai, "The invasive aquatic macrophyte, water hyacinth \{Eichhornia crassipes (Mart.) Solm-Laubach: Pontederiaceae $\}$ : problems and prospects," Res. J. Environ. Sci. 5, 509-520 (2011).

27. T. Dube, W. Gumindoga, and M. Chawira, "Detection of land cover changes around Lake Mutirikwi, Zimbabwe, based on traditional remote sensing image classification techniques," Afr. J. Aquat. Sci. 39(1), 89-95 (2014).

28. K. D. Getsinger et al., Benefits of Controlling Nuisance Aquatic Plants and Algae in the United States, QTA2014-1, Council for Agricultural Science and Technology, Ames (2014).

29. M. P. Hill and J. Coetzee, "The biological control of aquatic weeds in South Africa: current status and future challenges," Afr. Biodivers. Conserv. 47(2), a2152 (2017).

30. J. M. Halstead et al., "Hedonic analysis of effects of a nonnative invader (Myriophyllum heterophyllum) on New Hampshire (USA) lakefront properties," Environ. Manag. 32(3), 391-398 (2003).

31. H. R. Murkin and J. A. Kadlec, "Relationships between waterfowl and macro-invertebrate densities in a northern prairie marsh," J. Wildlife Manag. 50, 212-217 (1986).

32. M. Meerhoff et al., "An experimental study of habitat choice by Daphnia: plants signal danger more than refuge in subtropical lakes," Freshw. Biol. 51(7), 1320-1330 (2006).

33. I. Stiers et al., "Impact of three aquatic invasive species on native plants and macroinvertebrates in temperate ponds," Biol. Invasions 13, 2715-2726 (2011).

34. A. M. Villamagna and B. R. Murphy, "Ecological and socio-economic impacts of invasive water hyacinth (Eichhornia crassipes): a review," Freshwater Biol. 55, 282-298 (2010).

35. S. Khanna et al., "An integrated approach to a biophysiologically based classification of floating aquatic macrophytes," Int. J. Remote Sens. 32(4), 1067-1094 (2011).

36. G. Chandra et al., "Host plant preference of Mansonia mosquitoes," J. Aquat. Plant Manage. 44, 142-144 (2006).

37. N. Minakawa et al., "Recent reduction in the water level of Lake Victoria has created more habitats for Anopheles funestus," Malar. J. 7(119), 1-6 (2008).

38. R. J. Wilcock et al., "The influence of aquatic macrophytes on the hydraulic and physicchemical properties of a New Zealand lowland stream," Hydrobiologia 416, 203-214 (1999).

39. L. Thouvenot, J. Haury, and G. Thiebaut, "A success story: water primroses, aquatic plant pests," Aquat. Conserv: Mar. Freshwater Ecosyst. 23, 790-803 (2013).

40. L. G. Holm, L. W. Weldon, and R. D. van Blackburn, "Aquatic weeds," Science 166(3906), 699-709 (1969).

41. E. Vermuyten et al., "Impact of seasonal changes in vegetation on the river model prediction accuracy and real-time flood control performance," J. Flood Risk Manage. 13, e12651 (2020).

42. W. N. Rushing, "Waterhyacinth research in Puerto Rico," Hyacinth Control J. 12, 48-52 (1974).

43. J. S. Clayton and P. D. Champion, "Risk assessment method for submerged weeds in New Zealand hydroelectric lakes," Hydrobiologia 570, 183-188 (2006).

44. J. Lu et al., "Water hyacinth in China: a sustainability science-based management framework," Environ. Manage. 40, 823 (2007).

45. D. Tewabe, "Preliminary survey of water hyacinth in Lake Tana, Ethiopia," Glob J Allerg. 1, 013-018 (2015).

46. D. F. Spencer and G. G. Ksander, "Seasonal growth of waterhyacinth in the Sacramento/San Joaquin Delta, California," J. Aquat. Plant Manage. 43, 91-94 (2005).

47. R. W. Jones, "The impact on biodiversity, and integrated control, of water hyacinth, Eichhornia crassipes (Martius) Solms-Laubach (Pontederiaceae) on the Lake Nsezi-Nseleni river system," Doctoral diss., Rhodes University, Grahamstown, South Africa (2009).

48. J. C. Ritchie, P. V. Zimba, and J. H. Everitt, "Remote sensing techniques to assess water quality," Photogramm. Eng. Remote Sens. 69, 695-704 (2003).

49. T. Dube et al., "Water quality monitoring in sub-Saharan African lakes: a review of remote sensing applications," Afr. J. Aquat. Sci. 40, 1-7 (2015). 
50. A. Monteiro et al., "Water hyacinth (Eichhornia crassipes) in Portugal: synopsis of its bioecology and management," in Atas del IX Congreso de la Sociedad Española de Malherbología, Barcelona, pp. 89-103 (2003).

51. A. R. Guerreiro, "O jacinto aquático Eichhornia crassipes (Mart.) Solms em Portugal," Paper presented at the II Simpósio Nacional Herbologia, Oeiras, pp. 1-17 (In Portuguese) (1976).

52. W. Turner et al., "Satellites: make data freely accessible," Nature 498, 37 (2013).

53. E. L. Hestir et al., "Identification of invasive vegetation using hyperspectral remote sensing in the California Delta ecosystem," Remote Sens. Environ. 112, $4034-4047$ (2008).

54. N. C. Penatti et al., "Satellite based hydrological dynamics of the world's largest continuous wetland," Remote Sens. Environ. 170, 1-13 (2015).

55. H. W. Carson, L. W. Lass, and R. H. Callihan, "Detection of yellow hawkweed (Hieracium pratense) with high resolution multispectral digital imagery," Weed Technol. 9, 477-483 (1995).

56. C. S. Mladinich et al., "The use of Landsat 7 enhanced thematic mapper Plus for mapping leafy spurge," Rangel. Ecol. Manage. 59, 500-506 (2006).

57. P. Cuneo, C. R. Jacobson, and M. R. Leishman, "Landscape scale detection and mapping of invasive African Olive (Olea europaea L. ssp. cuspidata Wall ex G. Don Ciferri) in SW Sydney, Australia using satellite remote sensing," Appl. Veg. Sci. 12, 145-154 (2009).

58. M. M. Kimothi et al., "Remote sensing to map the invasive weed, Lantana camara in forests," Trop. Ecol. 51, 67-74 (2010).

59. C. Giardino et al., "Airborne hyperspectral data to assess suspended particulate matter and aquatic vegetation in a shallow and turbid lake," Remote Sens. Environ. 157, 48-57 (2015).

60. S. C. J. Palmer, T. Kutser, and P. D. Hunter, "Remote sensing of inland waters challenges, progress and future directions," Remote Sens. Environ. 157, 1-8 (2015).

61. J. Müllerová, J. Pergla, and P. Pyšek, "Remote sensing as a tool for monitoring plant invasions: testing the effects of data resolution and image classification approach on the detection of a model plant species Heracleum mantegazzianum (giant hogweed)," Int. J. Appl. Earth Obs. Geoinf. 25, 55-65 (2013).

62. C. Joshi et al., "Remotely sensed estimation of forest canopy density: a comparison of the performance of four methods," Int. J. Appl. Earth Obs. Geoinf. 8, 84-95 (2006).

63. E. K. Cheruiyot et al., "Evaluating MERIS-based aquatic vegetation mapping in Lake Victoria," Remote Sens. 6, 7762-7782 (2014).

64. E. Ghaderpour et al., "Non-stationary and unequally spaced NDVI time series analyses by the LSWAVE software," Int. J. Remote Sens. 41(6), 2374-2390 (2020).

65. G. Singh et al., "A remote sensing method to monitor water, aquatic vegetation, and invasive water hyacinth at national extents," Remote Sens. 12, 4021 (2020).

66. D. M. Lodge et al., "Biological invasions: recommendations for U.S. policy and management," Ecol. Appl. 16, 2035-2054 (2006).

67. B. A. Bradley and J. F. Mustard, "Characterizing the landscape dynamics of an invasive plant and risk of invasion using remote sensing," Ecol. Appl. 16, 1132-1147 (2006).

68. S. Dufour, P. M. Rodríguez-González, and M. Laslier, "Tracing the scientific trajectory of riparian vegetation studies: main topics, approaches and needs in a globally changing world," Sci. Tot. Environ. 653, 1168-1185 (2019).

69. R. J. Boothroyd, M. Nones, and M. Guerrero, "Deriving planform morphology and vegetation coverage from remote sensing to support river management applications," Front. Environ. Sci. 9, 657354 (2021).

70. A. Datta et al., "Monitoring the spread of water hyacinth (Pontederia crassipes): challenges and future developments," Front. Ecol. Evol. 9, 631338 (2021).

71. G. Venugopal, "Monitoring the effects of biological control of water hyacinth using remotely sensed data: a case study of Bangalore, India," Singap. J. Trop. Geogr. 19(1), 91-105 (1998).

72. H. J. Cho, P. Kirui, and N. Natarajan, "Test of multispectral vegetation index for floating and canopy-forming submerged vegetation," Int. J. Environ. Res. Pub. Health 5, 477-483 (2008). 
73. T. Dube et al., "Testing the detection and discrimination potential of the new Landsat 8 Satellite data on the challenging water hyacinth (Eichhornia crassipes) in freshwater ecosystems," Appl. Geogr. 84, 11-22 (2017).

74. IPMA - Instituto Português do Mar e da Atmosfera, "Normais climatológicas," https://www .ipma.pt/pt/oclima/normais.clima/ (In Portuguese) (accessed 25 August 2021).

75. IPMA - Instituto Português do Mar e da Atmosfera, "Ficha climatológica 1971-2000," https://www.ipma.pt/bin/file.data/climate-normal/cn_71-00_MONTEMOR_O_VELHO .pdf (In Portuguese) (accessed 25 August 2021).

76. C. Kasselmann, Aquarienpflanzen, pp. 1-472, Egen Ulmer GMBH \& Co., Stuttgart (In German) (1995).

77. M. I. P. de Lima and J. L. M. P. de Lima, "Precipitation and hydrology of the Mondego catchment: a scale invariant study," in Aquatic Ecology of the Mondego River Basin: Global Importance of Local Experience, M. A. Pardal, J. C. Marques, and M. A. Graça, Eds., pp. 13-28, Imprensa da Universidade de Coimbra: Coimbra (2002).

78. P. P. Cunha and J. Dinis, "Sedimentary dynamics of the Mondego estuary," in Aquatic Ecology of the Mondego River Basin: Global Importance of Local Experience, M. A. Pardal, J. C. Marques, and M. A. Graça, Eds., pp. 43-62, Imprensa da Universidade de Coimbra, Coimbra (2002).

79. Sentinel Scientific Data Hub, https://scihub.copernicus.eu/ (accessed 3 August 2021).

80. J. W. Rouse et al., "Monitoring the vernal advancement and retrogradation (Green wave effect) of natural vegetation," Final Rep. RSC 1978-4, Texas A\&M University, Remote Sensing Center, College Station (1974).

81. S. K. McFeeters, "The use of the normalized difference water index (NDWI) in the delineation of open water features," Int. J. Remote Sens. 17(7), 1425-1432 (1996).

82. B. Gao, "NDWI: a normalized difference water index for remote sensing of vegetation liquid water from space," Remote Sens. Environ. 58(3), 257-266 (1996).

83. M. T. Schaefer and D. W. Lamb, "A combination of plant NDVI and LiDAR measurements improve the estimation of pasture biomass in tall fescue (Festuca arundinacea var. Fletcher)," Remote Sens. 8(2), 109 (2016).

84. J. Serrano, S. Shahidian, and J. Marques da Silva, "Evaluation of normalized difference water index as a tool for monitoring pasture seasonal and inter-annual variability in a mediterranean agro-silvo-pastoral system," Water 11, 62 (2019).

85. P. Ceccato, S. Flasse, and J. M. Grégoire, "Designing a spectral index to estimate vegetation water content from remote sensing data: part 2. Validation and applications," Remote Sens. Environ. 82, 198-207 (2002).

86. Y. Gu et al., "A five-year analysis of MODIS NDVI and NDWI for grassland drought assessment over the central Great Plains of the United States," Geophys. Res. Lett. 34, L06407 (2007).

87. L. Fusilli et al., "Assessment of the abnormal growth of floating macrophytes in Winam Gulf (Kenya) by using MODIS imagery time series," Int. J. Appl. Earth Obs. Geoinf. 20, 33-41 (2013).

88. IPMA-Instituto Português do Mar e da Atmosfera, "Boletim climatológico anualPortugal Continental 2017," https://www.ipma.pt/resources.www/docs/im.publicacoes/ edicoes.online/20180315/GLoWcBXPqGauRNYDpUAC/cli_20171201_20171231_pcl_aa_ co_pt.pdf (In Portuguese) (accessed on 25 August 2021).

89. C. Vis, C. Hudon, and R. Carignan, "An evaluation of approaches used to determine the distribution and biomass of emergent and submerged aquatic macrophytes over large spatial scales," Aquat. Bot. 77(1), 87-201 (2003).

90. E. C. Underwood et al., "Mapping invasive aquatic vegetation in the Sacramento-San Joaquin Delta using hyperspectral imagery," Environ. Monit. Assess. 121, 47-64 (2006).

91. R. Vidhya et al., "Improved classification of Mangroves health status using hyperspectral remote sensing data," ISPRS Int. Arch. Photogramm. Remote Sens. Spat. Inf. Sci. XL-8, 667-670 (2014).

Romeu Gerardo received his BSc degree in environmental engineering in 2005 from the Polytechnic Institute of Coimbra and his MSc degree in environmental engineering in 2008 from 
the University of Coimbra. He is a research fellow at the University of Coimbra. He is an author of 9 book chapters and more than 20 articles and proceedings. His current research interests include remote sensing, water management, invasive plants, and precision agriculture.

Isabel P. de Lima holds her PhD in the specialization area of hydraulics, water resources, and environment. She is a professor at the University of Coimbra and a senior researcher at Marine and Environmental Sciences Centre. Her research topics include the application of scaling and multifractal theories in hydroclimatology, trends in hydroclimatic variables, soil and water conservation and management, and remote sensing environmental monitoring tools. 